Int. J. Electrochem. Sci., 11 (2016) $8994-9006$

International Journal of

ELECTROCHEMICAL

SCIENCE

www.electrochemsci.org

\title{
Co/CoO Nanoparticles/Ag Nanowires/Nitrogen Codoped Electrospun Carbon Nanofibers as Efficient Electrocatalysts for Oxygen Reduction
}

Supeng Peil,2,*, Zongshang Zhou ${ }^{1}$, Xiaohong Chen ${ }^{2}$, Xiongjie Huang ${ }^{2}$, Tong Liu $^{2}$, Boyu Cao $^{2}$ and Fei Wang $^{2}$

${ }^{1}$ School of Chemical and Environmental Engineering, Shanghai Institute of Technology, Shanghai 201418, China.

${ }^{2}$ School of Chemistry and Chemical Engineering, Shanghai Jiao Tong University, Shanghai 200240, China.

*E-mail: peisupeng@126.com

doi: $10.20964 / 2016.11 .52$

Received: 15 July 2016 / Accepted: 14 September 2016 / Published: 10 October 2016

Development of efficient electrocatalysts for oxygen reduction reaction (ORR) is of crucial importance to optimize the performance of fuel cells. In this work, Firstly, Ag nanowires (AgNWs) were in-situ embedded in electrospun carbon nanofibers (CNF). Then, Nitrogen and $\mathrm{Co} / \mathrm{CoO}$ nanoparticles (Co/CoO NPs) were successively codoped into CNF-AgNWs via the thermal annealing process, aiming to increase the accessible surface area of CNF-AgNWs and facilitate $\mathrm{O}_{2}$ diffusion and $\mathrm{OH}^{-}$ transport of the resulting N-CNF-AgNWs-Co/CoO hybrids. It is demonstrated that N-CNF-AgNWs$\mathrm{Co} / \mathrm{CoO}$ exhibited excellent electrocatalytic activity for the ORR in alkaline electrolytes, including high onset potential $(-0.069 \mathrm{~V})$, high half-wave potential $(-0.246 \mathrm{~V})$, and large electron transfer number ( 4).

Keywords: Ag nanowires; $\mathrm{Co} / \mathrm{CoO}$ nanoparticles; nitrogen-doping; carbon nanofibers; oxygen reduction reaction

\section{$\underline{\text { FULL TEXT }}$}

(C) 2016 The Authors. Published by ESG (www.electrochemsci.org). This article is an open access article distributed under the terms and conditions of the Creative Commons Attribution license (http://creativecommons.org/licenses/by/4.0/). 